\title{
DEPORTATION OF “KULAK” FAMILIES
}

\author{
Khudoyorov Noyibjon Maripdjanovich \\ Senior Lecturer of Department of History of Uzbekistan of Andizhan State University, Andizhan \\ region, Republic of Uzbekistan
}

Article DOI: https://doi.org/10.36713/epra8611

DOI No: 10.36713/epra8611

\begin{abstract}
-
The article details the horrific deportations carried out by the former Soviet Union among the population in order to develop agriculture, the deportation of innocent peasants to the undeveloped remote areas with limited rights to labor, and their details.
\end{abstract}

KEY WORDS: Exile, resettlement policy, nationalism, tolerance, self-government, Soviet power, peasant class, counter-revolutionary movement, collectivization, commandant's office, violence, entrepreneurship.

\section{INTRODUCTION}

The Soviet policy and practice of collectivization was characterized by the Red Empire waging a violent war against the peasants. It is clkulakly based on indifference, haste and irregularities in the interests and mood of the peasants. It is a historical fact that the latest scientific reskulakch has proven that collectivization is a practice of violence against the peasant masses. One of the tragedies associated with collectivization and left an ominous mark on the lives of farmers was the labeling of entrepreneurs and business farmers as "kulaks". From the kulakly days of the 1930s, the Politburo of the Central Committee of the CPSU (b) made a strategic decision about the fate of wealthy peasants in the countryside. Deafness and, in connection with it, the "kulak exile" has become the most pressing issue of political practice. One of the worst manifestations of the violence associated with collectivization and the abolition of "kulak" farms was their deportation. Such a mass humiliation of the peasants by the dictatorial regime, the violation of human rights and dignity, was an unprecedented criminal act of arbitrariness, which became a black page in the history of that regime.

\section{RESKULAKCH METHODS}

The decision on the deportation was made individually, and control of the deportees was entrusted to the local GPU authorities. Exiles are shown to live in the places they designate and register every three days. According to the amendment to the decree, a special commission under the NKVD is authorized to send certain categories of citizens to forced labor camps. With Stalin's announcement in late 1929 that he had moved from a policy of restricting and squeezing the kulaks to a "policy of annihilation as a class," the idea of planned relocation merged with the idea of collectivization, deafness, and "kulak exile". The decision of the Politburo of the Central Committee of the CPSU (b) of January 30, 1930 "On measures to eliminate kulak farms in areas of mass collectivization" became the legal basis for the transition to the policy and practice of mass deportation, a form of political repression in the collectivization process.

\section{RESULTS AND DISCUSSIONS}

On February 4, 1930, the secret instructions of the Central Executive Committee of the USSR "On the confiscation, deportation and resettlement of property of the kulaks" were sent to the Central Executive Committees of all allied and autonomous republics, regional and regional executive committees [1, p.42]. This secret instruction, signed by the Chairman of the Central Executive Committee of the USSR M. Kalinin, the 
Chairman of the Central Executive Committee of the USSR AI Rikov and the Secretary of the Central Executive Committee of the USSR A. Enukidze, is an important document.

The Secret Guide consists of three sections, 15 paragraphs, the first of which is entitled "Exile and Placement of kulaks". In order to resolutely eliminate the influence of the kulaks on certain sections of the poor and middle peasants and to suppress any attempts by the kulaks to resist the counter-revolutionary measures taken by the Soviet authorities and the collective farms:

According to the second paragraph of the Resolution of the Central Executive Committee of the USSR of February 1, 1930 "On measures to strengthen the socialist reconstruction of agriculture in the areas of mass collectivization and control of the kulaks" and deported from the province [2]. This decision was published in the newspaper "Izvestia" on February 2, 1930. However, in addition to the decision to make it possible to carry out its mass collectivization in other regions immediately, as far as possible, in other regions, the placement of other kulaks on new plots of land outside the kolkhoz within the area in which they live.

The third section of the secret directive sets out the "procedure for the placement of the remaining kulak farms" in the same district and district. The District Executive Committees are responsible for identifying settlements where the kulaks to be forcibly relocated are placed and managed by representatives appointed by a special committee (troika) or district committee and approved by the district committee. The settlers have a specific production task and the obligation to deliver goods to the state and cooperative bodies [3, p.6].

As kulakly as February 1930, the Sredazburo noted the need to develop a directive on the immediate abolition of second- and third-category kulak farms in the areas of mass collectivization. To this end, the establishment of plots for the establishment of "kulak settlements", the development of the use of exiled kulak farms as a target labor force, the appropriate form of administrative management of settlements was a representative appointed by the district executive committees. On September 15, 1931, the Central Committee of the Communist Party of Uzbekistan approved the instruction "On measures to eliminate the kulaks as a class in the areas of mass collectivization" and sent it to the places with a secret seal. The instruction consists of the following sections: "General instructions", "Procedure for deportation from the Uzbek SSR", "Procedure for deportation to kulak settlements in Uzbekistan", "Procedure and composition of deportation of kulaks in the region" (Category 3), "Procedure for confiscation of property" which was. Significantly, the hkulaking was performed on the basis of dividing the kulak farms into three categories. The first category of "kulaks" were participants in the anti-Soviet and anti-collective protests, who had to be imprisoned and their families exiled. The "big kulaks" of the second category and those who are active against collectivization are planned to be sent to faraway places with their families. Finally, the rest of the "kulaks" were in the third category, and they had to be relocated to barren lands within the republic, outside the area where collectivization was taking place. There are a number of uncertainties regarding the placement of third-category kulak families within the country, as local authorities were tasked with dealing with these categories, and in the kulakly ykulaks of exile there was no single center to keep track of them.

The real situation was such that violence and arbitrariness against the third category of farms were allowed on the ground. The "kulaks" of the third category were transferred to the second category, and even began to exceed the "norms" given above.

After the deportation of the "kulaks", new marks were added to them, and their human dignity continued to be insulted. They are now referred to as "exiles", "labor migrants", "special displaced persons', and so on. Not only the names of the "kulaks" but also the places where they lived in exile were given a special name, unlike ordinary settlements. The places where the former kulaks lived and worked in exile were called "labor settlements", "special settlements" and "kulak villages".

The first labor camps in Uzbekistan were established in 1930. Category 3 kulak farms were deported to these labor settlements. Between 1930 and 1931, 1,128 peasant families were deported from Central Asia to the interior of the region as kulak farms. The first kulak settlement mentioned in the documents was established in Jilvon village of Shafirkan district of Bukhara district. On March 15, 1930, 62 kulak farms of 250 people belonging to the 3rd category from Akmal Ikramov district, which is a mass collectivization district of Samarkand district, were located here [6]. For information, on March 24, 1930, at a closed meeting of the Executive Bureau of the Tashkent District Executive Committee of the Communist Party of Uzbekistan (b) on the issue of deportation and placement of kulaks in Tashkent district, a settlement was prepared for 20 farms in Parkent and 15 farms in the Golden Horde did it was also noted that a list of deportees in Mirzachul and Yangiyul districts has been compiled and checked. The number of kulaks of the third category in Mirzachul district is 72 farms, of which 41 are Russian and 32 are Uzbek. In Yangiyul district, 2 out of 108 farms were Russian and 106 were Uzbek. The meeting decided to deport the remaining 43 Russian farms out of a total of 181 kulak farms out of the district and to negotiate with the PP OGPU authorities. The Central Committee of the Communist Party of the Soviet Union (b) was asked to sanction the decision, but the issue was agreed with the 
Secretary of the Central Asian Bureau of the Central Committee of the Communist Party of the Soviet Union Zelensky [6]. OGPU data confirm that 30 farms from Mirzachul district and 167 farms from Yangiyul were forcibly relocated to the lands allocated outside the collective farms, leaving these kulak farms belonging to the third category in their districts [7]. In April-May 1932, 295 farms from Namangan region were deported to the interior of Uzbekistan as the third category of kulak farms.

The number of deportees in the villages was as follows: 24 farms from Lobangardon village (83 people), 28 farms from Sardoba village (126 people), 20 farms from Chukurkocha village ( 85 people), 20 farms from Deralik village (73 people), from Kyzylravot village 6 farms (24 people), 8 farms from Qoratikan village (40 people), 3 farms from Yastepa village (11 people), 7 farms from Aksi village (26 people), 2 farms from Ariqboyi village (10 people), from Darkata village 4 farms (12 people), 2 farms in Jiydalik village (7 people), 1 farm in Toshloq village (head of the farm Khudoykul Kholikulov), (5 people), 4 farms in Mashad village (18 people), 6 farms in Onhayot village (17 people), 1 farm from Chortuk village (Akbarhoji Nazarov), (4 people), 4 farms from Foyzobod village (14 people), 2 farms from Yorrkatay village (12 people), 11 farms from Yorjamo village (27 people), 8 farms from Yorchek village (30 people), 4 farms from Qatagansaray village (12 people), 4 farms from Kattaqurama village farms (22 people), 6 farms in Kichiktashbul village (27 people), 15 farms in Tepakurgan village (68 people), 11 farms in Kattatashbul village (43 people), 6 farms in Kyrgyzkurgan village (28 people), 9 people in Laskidon village farms (25 people), 13 farms in Durkun village (53 people), 3 farms in Kulkurgan village ( 8 people), 6 farms in Olakhamak village (22 people), 4 farms in Guldirov village (14 people), 5 farms in Beshkapa village farm (10 people), 6 farms from Kumkurgan village (21 people), 9 farms from Rayistan village (14 people), 3 farms from Qoratepa village (15 people), 8 farms from Irvodon village (36 people), 10 people from Khanabad village farm ( 28 people), 3 farms from Galcha village ( 8 people), 3 farms from Girvon village (13 people), 3 farms with undefined village ( 9 people) [8].

The names and surnames of these farms were distributed to echelon wagons prepared for deportation, signed by Matveev, the deputy head of the Namangan GPU, and Strunnikov, the assistant to the GPU representative. Based on this list, kulak farms were placed in pre-designated wagons [9]. The deaf "kulaks" from different districts of Surkhandarya, Bukhara, Samarkand and Andizhan districts were mainly relocated to the labor settlement of the state farm "Savay" in Andizhan district. Here is some information about some of the "kulak" families who were relocated to this labor settlement. Boymatov Khudoynazar, born in 1885, living in the village of Buyranish, Sariosiya district of Surkhandarya region, was listened to in 1932 and exiled with his family to the Savay cotton farm. His family consisted of his wife Ashurova Aysha, son Boymatov Khojanazar, and daughter Boymatova Gulsora. Berdiev Ergash is also from Karmana village, Sariosiya district of Surkhandarya region, and in 1932 he was exiled to the labor settlement in Savay [10]. His family included his wife, Zuhra, and his son, Dam.

Ashurov Yusup was born in 1898. From Karabanka village of Sariosiya district of Surkhandarya region. In May 1932, he and his family were deported to the Savai labor settlement. His family consisted of his wife Ashurova Khojar (born 1898) and daughter Ashurova Khilol (born 1932). Their sons Ashurov Kurban and Ashurov Sulaymon were born in exile.

Abdurahmanov Sattor was born in 1931. From Shurchi village of Denov district of Surkhandarya region. His family was deported in 1932 to the labor camp "Savay". The family, consisting of his mother Shaymuradova Onarkhon and sister Abdurahmanova Aydin, worked in the 7th department of the Savay state farm.

Khalikov Rahim was born in 1885. He lived in Chortuq village of Sariosiya district of Surkhandarya region. In 1932 he was "listened to" and exiled to the "Savay" cotton farm. He worked here in the 9th Division [11]. His wife was Khalikova Adolat (born in 1890), son Khalikov Yodgor (born in 1933), daughter Khalikova Adolat (born in 1890), son Khalikov Yodgor (born in 1933), daughter Khalikova Maharram (born in 1931), son Khalikov Botir (1942) born in [12].

Goyipov Nurmurad was born in 1903. From Khatirchi district of Samarkand district. In 1931, his farm was registered as an "kulak". According to the questionnaire, Goyipov took part in the anti-Soviet movement and sold his property. His family consisted of 12 people. His brother Goyipov Ulug was also persecuted as an "kulak". In 1931, Goipov Normurod had a cow, a horse, a donkey and a mare. Prior to the land reform, she had 9 tanobs of irrigated land, 48 tanob lalmi husbands, 2 oxen, 300 sheep, 3 cows, 2 donkeys, and one oilman. In 1930 he became a member of the kolkhoz. In 1931, he was expelled from the collective farm on charges of being an "kulak" and his brother was an "kulak" and was exiled with his family to the Stalin labor settlement in the Akkurgan district of the Tashkent region. In 1942, Goyipov Nurmurad's family was relocated to the Savay labor settlement [13]. In 1932 Mirzaeva Mamura from Jambay district of Samarkand district with her family, Umurzakov Tohir from Saroy village of Forish district, Shukurova Adolat oglu Shukurov from Romiton district of Bukhara district, Ergasheva Salomriashev from Shafirkan district of Shafirkan district of Samarkand region. 
exiled with. They were placed in this labor settlement and began to work in the cotton industry. At that time, the Savay cotton farm was short of manpower, and people from different districts were evacuated to fill the vacancies. They made a fruitful contribution to the restoration and development of the state farm with their labor. The "kulak exile" in Uzbekistan was formed from two main sources. First, in 1930-1931, "kulaks" belonging to the indigenous peoples of Central Asia were sent to the republic. Second, some of those deported from the national regions of the North Caucasus in 1933-1937 were also deported. In the mid-1930s, some old kulaks from southern regions that could not adapt to the natural conditions of Siberia or Kazakhstan were transplanted to labor settlements in Uzbekistan.

\section{CONCLUSION}

Thus, in the practice of collectivization of agriculture, the main focus was on "listening" to self-sufficient farms, confiscation of property and exile. This process was carried out very hastily, through violence, the use of force. In some regions of the country, the number of families deported and deported as a result of the ignorance of local leaders has been artificially increased. The OGPU authorities played a key role in the deportation of the kulaks families. The main part of the kulaks - those included in the 1st and 2nd categories - were deported from the republic. The remaining kulak families were relocated to special settlements in the republic. Collectivization and "listening", the deportation of peasants to distant lands, caused them great hardship and loss. At a certain stage in its history, our people have experienced such terrible trials. Thousands of entrepreneurs of the rural population were sentenced to miserable life, forced labor, and futile victims. Peasants and family members who were exiled for the historiography of the totalitarian regime were simply "anti-Soviet elements." The number of liquidated and deported kulak farms in Uzbekistan has not yet been fully determined. In addition, there are few documentary sources on the fate of the "kulaks" deported to Uzbekistan. This situation limits the scope of a thorough analysis and study of the issue.

\section{REFERENCES}

1. Politburo and the peasantry: deportation, special settlement. 1930-1940: In 2 books. Book 1 - P. 62 -65; The tragedy of the Central Asian village ... V.1. - p. 612-616.

2. Tragedy of the Central Asian village ... V.1. - p. 323

3. The tragedy of the Central Asian village ... - P. 615.

4. Karimov N., Shamsutdinov R. Memory of the Martyrs. Exile. T., G. Gulom Publishing House of Literature and Art. 2000, - p. 6-7.

5. Zemskov V.N. Special settlers in the USSR ... 17-18 p.

6. Tragedy of the Central Asian village ... V.1. - p.617 - 618.

7. Tragedy of the Central Asian village ... V.2. - P.272-273.

8. Namangan regional state archive, fund 13 , list 1 , case 523 , pages 50-59.

9. Namangan regional state archive, fund 13, list 1, case 523, pages 50-59.

10. Archive of the Department of Internal Affairs of Andizhan region, fund 16, case 16261, page 17.

11. Archive of the Department of Internal Affairs of Andizhan region, fund 16, case 16261, case 16280, page 22

12. Archive of the Department of Internal Affairs of Andizhan region, Fund 16, Case 16327, 14.2.19. Pages 18-19.

13. Archive of the Department of Internal Affairs of Andizhan region Fund 16, Case 16195, pp. 17-23. 